\title{
Relationship between Cooperation, Competition and Family Background at the Ages of 8-18 in a Hungarian Context
}

\author{
László Kasik \\ University of Szeged, Faculty of Arts, Institute of Education \\ University of Szeged, Social Competence Research Group
}

\begin{abstract}
The aim of the cross-sectional study was to investigate the development of dimensions of cooperation and competition (e.g. interest, share, exclusion, time of competition) and to examine the correlations between dimensions and some characteristics of family (e.g. parents' educational level; family type) at the ages of $8-18(\mathrm{~N}=745)$ in a Hungarian context. In the case of the cooperation and competition dimensions, beside children's own evaluations, mothers $(\mathrm{N}=745)$ and teachers $(\mathrm{N}=36)$ also evaluated the children's cooperation and competition (with the same questionnaire). The mothers filled in the list of family background. The results show that some dimensions of cooperation and competition have a strong correlation with age and some factors significantly determine each other before high school years (e.g. conflict of interest, exclusion from a group, respecting rules of competition). The relations between these dimensions do not change during high school years. Based on the total values (means of the raters), the most dimensions of cooperation and competition show increasing tendency with age. The relationship between the values of factors of children and mothers is the strongest in all age groups. In the case of 15- and 18-year-olds the school type differences are significant. The factors are influenced the most by family type, and mothers' and fathers' educational level have a lower effect on dimensions in all age groups. The effects of free time activities in family are stronger than those of the time spent on learning in all age groups. The net income is the environment variable that has the smallest effect on the functioning of cooperation and competition.
\end{abstract}

Keywords: cooperation; competition; family background; parent-child-teacher correlation 


\section{Introduction}

Several studies agree that within social behaviour the way of cooperation and competition have a great influence on success in personal life, on psychic health (e.g. Bremer \& Smith, 2004; Decety, Jackson, Sommerville, Chaminade, \& Meltzoff, 2004), on academic and professional success (e.g. Van der Zee, Thijs, \& Schakel, 2002), and on the functioning of different social groups and society (e.g. Bettencourt \& Sheldon, 2001; Fiske, 2006; Fülöp, 2009). Many investigations have shown that academic achievement, social environment and psychic health each have a growing impact on social behaviour as one gets older (e.g. Green, Forehand, Beck, \& Vosk, 1980; Md Aris Safree \& Mariam Adawiah, 2011), hence, reciprocal causality can be supposed between these factors and social behaviour.

Fülöp (1995) claims that the definition of cooperation and competition was influenced by Deutsch's theory (1949) in the second half of the $20^{\text {th }}$ century. Deutsch defined the difference between cooperation and competition on the basis of the two basic types of goal interdependence (positive and negative). Positively interdependent goals normally result in cooperative situations because any participant can "attain his goal if, and only if, the others with whom he is linked can attain their goals. Negatively interdependent goals force competitive situations because the only way for one side to achieve its goals is for the other side not to" (Deutsch, 2000. p. 22.). According to Deutsch, "in cooperation the focus is not on the individual, whereas competition heightens ego demands. In this latest case the ego objective becomes more important than others' aims and the common goal" (cited in Orosz, 2009. 96.). Deutsch's theory affected psychological research powerfully, and defined the educational practice of many countries, for example that of Hungary (Fülöp, 2010).

According to McClintock (1976) the connection between these two behaviours is inverse: if a person is highly cooperative, then s/he shows only little competitive behavior, and vice versa. Schroeder et al. (1995) identify the difference between the two behaviours on the basis of the characteristics of prosocial behaviour. The goal of prosocial behaviour is to fulfil other people's needs. Helping, altruism and cooperation are examples of prosocial behavior, but competition is not considered to belong to this group (Fiske, 2006). According to Schroeder et al. (1995), when cooperating, people consider their own and others' interests and they aim to maximise both. However, in the 
case of competition, the aim is the realisation of our own interest. Nevertheless, Charlesworth (1996) claims that besides manipulation and aggression, cooperation is a variant of competition. He regarded it as a very important competitive human strategy (Fülöp, 2008).

Trivers (1985) claims that the aim of cooperation is to achieve common goals. Monitoring others' contribution is very important in cooperation and the manner of contributions affects the share. If someone does not contribute to the accomplishment of common goals in the group, members may exclude him/her. According to Baron (1997), when group members cooperate, they realise their own, others' and common (group) interests at the same time. This phenomenon cannot be grasped if we continue to think about cooperation and competition as incompatible concepts. Hence self-interest realisation does not necessarily result in competitive behaviour. Pruitt (1998) agrees with Baron that in the case of cooperation it is possible to clearly separate the determination of goals, contribution and sharing led by self-interest and the same behaviours motivated by a caring for the interest of others. Competition is defined by Fülöp (1995. p. 42.) in the following way: "[It is a]n interactional process derived from inner needs or external/contextual requirement, which implicates two or more persons or groups who deciding their chances commensurable strive for primacy in a given field. Competition is generated among individuals if they belong(ed) to the same group or if they will belong to the same group. Competition emerges always on the basis of a well-defined context which is characterized by its own values, norms and aims." (cited in Orosz, 2009. 104.). According to Fülöp (2003) the basic competition dimensions are resources, duration of competition, goal (for example one's own success or beating the rival), equality, rulefollowing and self-control and the control by others.

Relying on anthropological and human ethological studies (e.g. Csányi, 1999; Fiske, 1992), Nagy (2000) claims that main goal of cooperation is sharing and the primary aims of competition are achievement and defence. The fundamental dimensions of cooperation are contribution, share, group interest and exclusion from the group. In the case of competition these dimensions are regularity, control and proportional risk. As for inner needs, the principal interest in cooperation is collective interest, and in the case of competition this is conflict of interests. However, relying on the dimension-based view Nagy (2000) also emphasises that cooperation and competition have some common segments. In the last two decades, dimension-based investigations showed that some 
dimensions of cooperative and competitive behaviours have a strong correlation with age (e.g. Charlesworth, 1996; Van de Vliert, 1999; Fülöp, 2010).

According to the theoretical works, Fiske (2006) and Fülöp (2007) emphasize that cooperation and competition are complex systems. These behaviours consist of a number of components, usually called dimensions, and these dimensions are related to the dimensions of other behaviours. Thus the relations between complex behaviours are actually realized by relations between the dimensions of the relevant behaviours. I share Fülöp's view (2007) that only this dimension-based approach results in the adequate assessment of these behaviours. Nowadays, many international studies use the dimension-based view (e.g. Pruitt, 1998). However, only few studies have investigated cooperation and competition in a Hungarian context based on this approach. According to international research, the functioning of these behaviours and their relations change over time (e.g. Fiske, 2006), however, in most cases these are studied separately in Hungary.

Observational studies show that the competitive behaviour is already present among three-year-olds (Fülöp, 2007; Strayer, 1989). Also, cooperation was found to be closely related activities (e.g. Hartup, 1992). Individual and cultural differences on these behaviours can be detected from early years on (e.g. Eisenberg, 1982). According to Fülöp (2007) the choice of competitive situations is frequent among five-year-old children and they can already define the concept of competition. 9- and 10-year-olds attach the notions of winning and losing to the definition of competition. However, these definitions are usually attached to competitive situations at school.

The international research emphasizes that social activity largely depends on the characteristics of parental child-rearing practices (e.g. Schneider, 1993). Keith and Campbell (2000) reported that family was the most important factor influencing the social development of a child. Ladd (2000) claims that a child who cannot acquire the basics of social behaviour in the early years in the family, may have trouble with social interactions when they become adults. Lata and Chhikra (1995) concluded that socioeconomic factors (education, profession of parents, income) were significantly associated with adaptive social behaviour of children.

Grusec (1992) proposes that the frequency of cooperation depends on parents' patterns (frequency and quality are determined by norms and rules of society). Caprara et al.'s (1990) investigations showed that those adolescents (15-year-olds) who saw good examples of cooperation more often show cooperation. Also in adolescence, the dominance relations in a group (for example in a class) change, and social comparison 
will be a very important component of competition. The aim of competition is to get a high position in a group (Fülöp, 2007).

\section{The dimension-based model of our study}

I agree with Fülöp (2007) that only the dimension-based view results in an adequate assessment of social behaviours and that their connections with other areas can be investigated exclusively with this model. In my study, I rely on Fiske's (1992) and Nagy's (2000) models. According to Fiske, the studied behaviours reveal the two basic aims of social activity: cooperation is related to sharing and competition to achievement and defence. Based on socio-anthropological theory, Nagy (2000) identified specific dimensions of the two behaviours (cooperation: contribution and share; competition: equality and control). These models were complemented with some ethological, social psychological and pedagogical aspects (Eibl-Eibesfeldt, 1989; Csányi, 1999; Fiske, 2006; Fülöp, 2007). We have identified some major and minor dimensions within all forms of behaviour (Table 1).

Table 1: Major and minor dimensions of cooperation and competition

\begin{tabular}{|c|c|c|}
\hline Behaviours & Major dimension & Minor dimension \\
\hline \multirow[t]{3}{*}{ Cooperation } & Contribution and share & $\begin{array}{l}\text { Contribution: maximisation } \\
\text { Contribution: minimisation } \\
\text { Share: depends on contribution } \\
\text { Share: does not depend on contribution }\end{array}$ \\
\hline & Exclusion & $\begin{array}{l}\text { Achievement as cause } \\
\text { Claim as cause }\end{array}$ \\
\hline & Interest & $\begin{array}{l}\text { Interest } \\
\text { Conflict of interests }\end{array}$ \\
\hline \multirow{4}{*}{ Competition } & Duration & $\begin{array}{l}\text { Duration of competition } \\
\text { Time of announcing results }\end{array}$ \\
\hline & Winner & Number of winners \\
\hline & Interest and preference & $\begin{array}{l}\text { Relationship between myself and others } \\
\text { Function of myself and others }\end{array}$ \\
\hline & Equality and control & $\begin{array}{l}\text { Chance } \\
\text { Expectations }\end{array}$ \\
\hline \multicolumn{3}{|c|}{$\begin{array}{l}\text { Within cooperation the major dimensions are Contribution and share (maximisation an } \\
\text { minimisation of the work; accepting reward: does it depend on the amount o } \\
\text { contribution or not), Exclusion (cause of exclusion: group work as achievement, clain } \\
\text { about reward) and Interest (realisation of one's own interest; conflict of interests). Withi }\end{array}$} \\
\hline
\end{tabular}


either the competitive situation itself or the period of time after the competition; when the child wants to know the result of a competition but he/she still has to wait for it); Winner (how many winners there will be - importance of the number of winners at the beginning of competition); Interest and preference (relationship between oneself and another one in a competitive situation - the mean goal is one's own success and beating the rival) and Equality and control (one's own and other's chance is the same; compliance with parents', teachers' and peers' expectations in connection with competition).

\section{Aims and hypotheses of our study}

The specific aims of our cross-sectional research were to describe the developmental level of some dimensions of cooperation and competition at the ages of 8, 12, 15 and 18 (school type differences, too); to examine the relations between different raters' judgements on children's cooperation and competition; and to investigate the relations between cooperation, competition and family background.

The hypotheses there are. Age. We hypothesised that significant differences due to age could be identified with regard to the functioning of the cooperation and competition factors, and it is mainly the 8- and 12-year-old children and the 15- and 18-year-old children that differ the most.

School type. Earlier Hungarian studies emphasize (e.g. Csapó, 2001) that school type (within high school system) has a significant influence on students' social and academic achievement. Family background plays an essential role in this because the socio-economic status of families influences what type of school parents choose for their children. It was hypothesised in our study that significant differences can be identified among children of different school types $(\mathrm{g}=$ grammar school, $\mathrm{s}=$ secondary vocational school, $\mathrm{v}=$ vocational school) among the 15- and 18-year-olds. We assumed that in most cases students of vocational schools differ from grammar school- and secondary vocational school students; or that it is grammar school students who show significantly different results than the two other groups.

Raters' judgements. We hypothesised that raters' opinions about the factors are very divergent; and that children's and the parents' ratings of children's social behaviours show more similarity than children's and the teachers' ratings or teachers' and parents' ratings. 
Correlations between the factors. A number of previous studies revealed (e.g. Eisenberg, 1982; Fiske, 2006) that the dimensions of several social behaviours are related to each other and the relationship may already be strong in the early years. However, the connections may change with age and many dimensions show low (or no) correlations with other dimensions.

Correlations between factors and family background. It was hypothesised that the effect of parents' highest educational qualification decreases with age, just as the role of net income. In contrast, we assumed that the impact of family type, free time activities in family and time spent on learning with child increase with age.

\section{Methods}

\section{Participants}

Our study was carried out among children of $8,12,15$ and 18 years of age $(\mathrm{N}=745)$ from 15 schools in Hungary. The sample was selected randomly. The size of the subsamples was approximately the same $(8=181 ; 12=186 ; 15=188 ; 18=190)$. Teachers $(\mathrm{N}=36)$ and parents (mothers, $\mathrm{N}=745$, mean age $\mathrm{M}=37.79, \mathrm{SD}=7.75$ ) also participated in the research, they rated children. Mothers also had to fill in the questionnaire about family background. The sample and the subsamples represented a range of Hungarian mothers' educational levels (1: elementary school $=19-26 \% ; 2$ : vocational school $=31-35 \% ; 3$ : high school $=33-38 \%$; 4 : college or university degree $=5-9 \%$; whole sample: $\chi^{2}=53.12, \mathrm{p}=.02$ ).

\section{Instruments - factor analysis, reliability and validity}

The functioning of the dimensions of cooperation and competition was assessed with an own questionnaire: Cooperation and Competition Questionnaire (CCQ, Kasik, 2008, 2010): children's self-assessment version (CCQ-C), a teacher (CCQ-T), and a parent version (CCQ-P). The questionnaires had 28 statements. The child and the adult versions share the same structure and scale items. The statements consist of 5-point (from 1 to 5) items: $1=$ =never, $2=$ generally not; $3=$ =sometimes, 4=generally yes, 5=always.

The factor analysis of the items restructured the theoretical dimensions to a large extent. The questionnaire items assigned to the two behaviours were grouped in five 
factors in all versions. The results of the factor analysis demonstrate the comprehensive nature of social behaviour. An individual's behaviour in a certain situation is influenced by the situation itself (SE: Situation and expectations -4 items), by the individual's attitude towards others in the situation and towards the situation (CS: Connection between contribution and share -4 items; DW: Duration and winner -5 items), by the individual's interest (I: Interest - 7 items), and by his/her interest appraisal and possible conflict of interests (ECE: Equal opportunity, conflict of interests, exclusion -8 items). Two factors (Interest; Equal opportunity, conflict of interests, exclusion) are combined factors, they have cooperation and competition items. One factor includes only cooperation items (Connection between contribution and share), and two factors have only competition (Situation and expectations, Duration and winner) items.

An item from the I factor is "The group work is good if the others do what I want."; SE factor: "I respect rules of competition because my peers expect this from me."; ECE factor: "If somebody does not work enough in the group, s/he has to be excluded from the group."; DW factor: "I compete with the others anytime." and finally AS factor: "During group work everybody has to get the equal amount of reward." The instrument exhibited a good reliability and validity in all age groups and for all versions (Table 2).

Table 2: Indices of reliability and validity of CCQ $(\mathrm{C}, \mathrm{P}, \mathrm{T})$

\begin{tabular}{|c|c|c|c|c|c|c|c|c|c|c|c|c|c|c|c|c|c|c|c|c|}
\hline \multirow[t]{3}{*}{ Index } & \multicolumn{5}{|l|}{8} & \multicolumn{5}{|l|}{12} & \multicolumn{5}{|l|}{15} & \multicolumn{5}{|c|}{18} \\
\hline & \multicolumn{5}{|c|}{ Child } & \multicolumn{5}{|c|}{ Child } & \multicolumn{5}{|c|}{ Child } & \multicolumn{5}{|c|}{ Child } \\
\hline & I & $\begin{array}{l}\mathrm{S} \\
\mathrm{E}\end{array}$ & $\begin{array}{l}\mathrm{E} \\
\mathrm{C} \\
\mathrm{E}\end{array}$ & $\begin{array}{l}\text { D } \\
\text { W }\end{array}$ & $\begin{array}{l}\mathrm{C} \\
\mathrm{S}\end{array}$ & I & $\begin{array}{l}\mathrm{S} \\
\mathrm{E}\end{array}$ & $\begin{array}{l}E \\
C \\
E\end{array}$ & $\begin{array}{l}\text { D } \\
\text { W }\end{array}$ & $\begin{array}{l}\mathrm{C} \\
\mathrm{S}\end{array}$ & I & $\begin{array}{l}\mathrm{S} \\
\mathrm{E}\end{array}$ & $\begin{array}{l}E \\
C \\
E\end{array}$ & $\begin{array}{l}\mathrm{D} \\
\mathrm{W}\end{array}$ & $\begin{array}{l}\mathrm{C} \\
\mathrm{S}\end{array}$ & I & $\begin{array}{l}S \\
E\end{array}$ & $\begin{array}{l}\mathrm{E} \\
\mathrm{C} \\
\mathrm{E}\end{array}$ & $\begin{array}{l}\mathrm{D} \\
\mathrm{W}\end{array}$ & $\begin{array}{l}\mathrm{C} \\
\mathrm{S}\end{array}$ \\
\hline $\begin{array}{l}\text { Cronba } \\
\text { ch- } \\
\text { alpha }\end{array}$ & $\begin{array}{l}.8 \\
6\end{array}$ & $\begin{array}{l}.7 \\
6\end{array}$ & $\begin{array}{l}.8 \\
9\end{array}$ & $\begin{array}{l}.8 \\
2\end{array}$ & $\begin{array}{l}.7 \\
9\end{array}$ & $\begin{array}{l}.9 \\
0\end{array}$ & $\begin{array}{l}.8 \\
8\end{array}$ & $\begin{array}{l}.8 \\
4\end{array}$ & $\begin{array}{l}.8 \\
8\end{array}$ & $\begin{array}{l}.9 \\
0\end{array}$ & $\begin{array}{l}.9 \\
2\end{array}$ & $\begin{array}{l}.8 \\
7\end{array}$ & $\begin{array}{l}.9 \\
1\end{array}$ & $\begin{array}{l}.8 \\
5\end{array}$ & $\begin{array}{l}.9 \\
2\end{array}$ & $\begin{array}{l}.9 \\
1\end{array}$ & $\begin{array}{l}.8 \\
5\end{array}$ & $\begin{array}{l}.9 \\
0\end{array}$ & $\begin{array}{l}.8 \\
6\end{array}$ & $\begin{array}{l}.9 \\
1\end{array}$ \\
\hline $\mathrm{KMO}$ & \multicolumn{5}{|l|}{.82} & \multicolumn{5}{|c|}{.85} & \multicolumn{5}{|c|}{.86} & \multicolumn{5}{|c|}{.88} \\
\hline \multirow[b]{3}{*}{$\begin{array}{l}\text { Cronba } \\
\text { ch- } \\
\text { alpha }\end{array}$} & \multicolumn{5}{|c|}{ Parent } & \multicolumn{5}{|c|}{ Parent } & \multicolumn{5}{|c|}{ Parent } & \multicolumn{5}{|c|}{ Parent } \\
\hline & I & $\begin{array}{l}S \\
E\end{array}$ & $\begin{array}{l}E \\
C \\
E \\
\end{array}$ & $\begin{array}{l}\mathrm{D} \\
\mathrm{W}\end{array}$ & $\begin{array}{l}\mathrm{C} \\
\mathrm{S}\end{array}$ & I & $\begin{array}{l}S \\
E\end{array}$ & $\begin{array}{l}\mathrm{E} \\
\mathrm{C} \\
\mathrm{E}\end{array}$ & $\begin{array}{l}\text { D } \\
\text { W }\end{array}$ & $\begin{array}{l}\mathrm{C} \\
\mathrm{S}\end{array}$ & I & $\begin{array}{l}\mathrm{S} \\
\mathrm{E}\end{array}$ & $\begin{array}{l}\mathrm{E} \\
\mathrm{C} \\
\mathrm{E}\end{array}$ & $\begin{array}{l}\mathrm{D} \\
\mathrm{W}\end{array}$ & $\begin{array}{l}\mathrm{C} \\
\mathrm{S}\end{array}$ & I & $\begin{array}{l}S \\
E\end{array}$ & $\begin{array}{l}\mathrm{E} \\
\mathrm{C} \\
\mathrm{E}\end{array}$ & $\begin{array}{l}\mathrm{D} \\
\mathrm{W}\end{array}$ & $\begin{array}{l}\mathrm{C} \\
\mathrm{S}\end{array}$ \\
\hline & $\begin{array}{l}.8 \\
9\end{array}$ & $\begin{array}{l}.9 \\
0\end{array}$ & $\begin{array}{l}.8 \\
8\end{array}$ & $\begin{array}{l}.8 \\
4\end{array}$ & $\begin{array}{l}.8 \\
0\end{array}$ & $\begin{array}{l}.8 \\
4\end{array}$ & $\begin{array}{l}.7 \\
9\end{array}$ & $\begin{array}{l}.9 \\
0\end{array}$ & $\begin{array}{l}.9 \\
1\end{array}$ & $\begin{array}{l}.8 \\
9\end{array}$ & $\begin{array}{l}.8 \\
5\end{array}$ & $\begin{array}{l}.7 \\
8\end{array}$ & $\begin{array}{l}.9 \\
1\end{array}$ & $\begin{array}{l}.9 \\
2\end{array}$ & $\begin{array}{l}.8 \\
8\end{array}$ & $\begin{array}{l}.8 \\
6\end{array}$ & $\begin{array}{l}.8 \\
1\end{array}$ & $\begin{array}{l}.8 \\
9\end{array}$ & $\begin{array}{l}.9 \\
1\end{array}$ & $\begin{array}{l}.7 \\
9\end{array}$ \\
\hline $\mathrm{KMO}$ & \multicolumn{5}{|l|}{.87} & \multicolumn{5}{|c|}{.89} & \multicolumn{5}{|c|}{.90} & \multicolumn{5}{|c|}{.88} \\
\hline & \multicolumn{5}{|c|}{ Teacher } & \multicolumn{5}{|c|}{ Teacher } & \multicolumn{5}{|c|}{ Teacher } & \multicolumn{5}{|c|}{ Teacher } \\
\hline & I & $\begin{array}{l}S \\
E\end{array}$ & $\begin{array}{l}\mathrm{E} \\
\mathrm{C} \\
\end{array}$ & $\begin{array}{l}\mathrm{D} \\
\mathrm{W} \\
\end{array}$ & $\begin{array}{l}\mathrm{C} \\
\mathrm{S} \\
\end{array}$ & I & $\begin{array}{l}S \\
E\end{array}$ & $\begin{array}{l}\mathrm{E} \\
\mathrm{C} \\
\end{array}$ & $\begin{array}{l}\mathrm{D} \\
\mathrm{W}\end{array}$ & $\begin{array}{l}\mathrm{C} \\
\mathrm{S} \\
\end{array}$ & I & $\begin{array}{l}\mathrm{S} \\
\mathrm{E}\end{array}$ & $\begin{array}{l}\mathrm{E} \\
\mathrm{C} \\
\end{array}$ & $\begin{array}{l}\mathrm{D} \\
\mathrm{W}\end{array}$ & $\begin{array}{l}\mathrm{C} \\
\mathrm{S} \\
\end{array}$ & I & $\begin{array}{l}\mathrm{S} \\
\mathrm{E} \\
\end{array}$ & $\begin{array}{l}\mathrm{E} \\
\mathrm{C} \\
\end{array}$ & $\begin{array}{l}\mathrm{D} \\
\mathrm{W} \\
\end{array}$ & $\begin{array}{l}\mathrm{C} \\
\mathrm{S} \\
\end{array}$ \\
\hline
\end{tabular}




\begin{tabular}{|c|c|c|c|c|c|c|c|c|c|c|c|c|c|c|c|c|c|c|c|c|}
\hline \multirow{3}{*}{$\begin{array}{l}\text { Cronba } \\
\text { ch- } \\
\text { alpha }\end{array}$} & \multicolumn{5}{|c|}{$\mathrm{E}$} & \multicolumn{5}{|c|}{$\mathrm{E}$} & \multicolumn{5}{|c|}{$\mathrm{E}$} & \multicolumn{5}{|c|}{$\mathrm{E}$} \\
\hline & .9 & .8 & .8 & .8 & .8 & .8 & .8 & .9 & .8 & .7 & .7 & .8 & .8 & .8 & .7 & .8 & .8 & .8 & .8 & .8 \\
\hline & 0 & 8 & 7 & 4 & 2 & 2 & 5 & 0 & 0 & 6 & 7 & 8 & 9 & 9 & 9 & 2 & 7 & 8 & 7 & 3 \\
\hline KMO & .89 & & & & & .85 & & & & & .87 & & & & & .87 & & & & \\
\hline
\end{tabular}

Note. I=Interest; SE=Situation and expectations; ECE=Equal opportunity, conflict of interests, exclusion; DW=Duration and winner; $\mathrm{CS}=$ Connection between contribution and share. KMO=Kaiser-Meyer-Olkin index.

Some characteristics of family background were examined by the Family Background Questionnaire (FBQ; Kasik, 2010) developed by us relying on a social psychological and a sociological approach (e.g. Grusec \& Davidov, 2007; Kohn, 1995; Schneider, 1993). The FBQ includes six sections: (1) family type (FT); (2) mother's educational level (MEL); (3) father's educational level (FEL); (4) net income (NI); (5) free time activities in family (FTA); (6) time spent on learning with child (TSL). The categories of FT are: $1=$ mother and father with one child; $2=$ mother and father with two or more children; $3=$ mother with one child; $4=$ mother with two or more children; $5=$ father with one child; $6=$ father with two or more children; $7=$ grandparent/s with child/ren; $8=$ other adult/s with child/ren; 9=child with older brother or older sister. The parents' (mother and father) educational levels are: 1=elementary school; 2=vocational school; 3=high school; $4=$ college or university degree. The NI section includes answers about the financial circumstances according to monthly per capita net incomes (based on the valid Hungarian income system): 1=very bad; 2=wrong; 3=average; 4=good; 5=excellent. FTA designates the time spent on a free time activity (e.g. play, watching TV, cinema or theatre, conversation) with children in a week: $1=$ less than 1 hour; $2=1-2$ hours; $3=2-3$ hours; 4=3-4 hours; 5=more than 4 hours. The TSL categories are the same as the FTA categories.

\section{Procedure}

Data collection took place in 2010. The students filled in the questionnaire at school in the classroom. Teachers and mothers completed the questionnaires during a parentteacher conference in the school. Also we asked fathers to fill in the questionnaire (CCQP), but only a few fathers did so (42 from $745 ; 6 \%$ ), consequently we only analyzed mothers' answers in this study and the word 'parents' refers actually to 'mothers'. 


\section{Results}

\section{Age differences of cooperation and competition factors}

In connection with age difference the hypothesis was confirmed. The ANOVA results are presented in Table 3. This table shows the results by raters (child, mother, teacher) and the cumulated indices (means of the three raters' judgements). Thick vertical lines indicate the division between subsamples that show significant differences.

Table 3: Results of factors of SIRB (M, SD and ANOVA: F, p)

\begin{tabular}{|c|c|c|c|c|c|c|c|}
\hline \multirow{2}{*}{$\begin{array}{l}\text { Rater/ } \\
\text { Cumulate } \\
\text { d indices } \\
\text { (CI) }\end{array}$} & \multicolumn{4}{|c|}{ Mean (M) / Age } & & \multicolumn{2}{|c|}{ ANOVA } \\
\hline & $\begin{array}{l}\text { Standard } \\
\text { Deviation } \\
\text { (SD) }\end{array}$ & 8 & 12 & 15 & 18 & $\mathrm{~F}$ & $\mathrm{p}$ \\
\hline \multicolumn{8}{|c|}{ INTEREST } \\
\hline \multirow{2}{*}{ Child } & $\mathrm{M}$ & .65 & .68 & .80 & .81 & \multirow{2}{*}{61.8} & \multirow{2}{*}{.00} \\
\hline & SD & .15 & .14 & .11 & .11 & & \\
\hline \multirow{2}{*}{ Mother } & M & .64 & .68 & .78 & .84 & \multirow{2}{*}{39.6} & \multirow{2}{*}{.00} \\
\hline & SD & .12 & .14 & .12 & .12 & & \\
\hline \multirow{2}{*}{ Teacher } & M & .61 & .65 & .74 & .79 & \multirow{2}{*}{24.2} & \multirow{2}{*}{.01} \\
\hline & SD & .16 & .17 & .13 & .11 & & \\
\hline \multirow{2}{*}{ CI } & $\mathrm{M}$ & .64 & .67 & .78 & .82 & \multirow{2}{*}{48.7} & \multirow{2}{*}{.00} \\
\hline & SD & .14 & .15 & .12 & .11 & & \\
\hline \multicolumn{8}{|c|}{ SITUATION AND EXPECTATIONS } \\
\hline \multirow{2}{*}{ Child } & M & .71 & .70 & .60 & .59 & \multirow{2}{*}{67.2} & \multirow{2}{*}{.00} \\
\hline & SD & .11 & .12 & .16 & .15 & & \\
\hline \multirow{2}{*}{ Mother } & M & .72 & .69 & .62 & .61 & \multirow{2}{*}{21.1} & \multirow{2}{*}{.02} \\
\hline & SD & .16 & .15 & .12 & .12 & & \\
\hline \multirow{2}{*}{ Teacher } & M & .69 & .67 & .56 & .57 & \multirow{2}{*}{24.6} & \multirow{2}{*}{.00} \\
\hline & SD & .15 & .13 & .11 & .11 & & \\
\hline \multirow{2}{*}{$\mathrm{CI}$} & $\mathrm{M}$ & .71 & .68 & .60 & .59 & \multirow{2}{*}{23.2} & \multirow{2}{*}{.01} \\
\hline & $\mathrm{SD}$ & .14 & .13 & .13 & .13 & & \\
\hline EQUAL O & PPORTUN & $\mathrm{CO}$ & $\mathrm{CT} \mathrm{C}$ & TER & EX & SIO & \\
\hline Child & $\mathrm{M}$ & .60 & .62 & .71 & .74 & 585 & 00 \\
\hline Child & SD & .14 & .12 & .13 & .14 & 58.5 & .00 \\
\hline & M & .58 & .61 & .70 & .72 & & \\
\hline Mother & SD & .12 & .14 & .15 & .13 & 28.6 & .00 \\
\hline Teacher & M & .62 & .63 & .69 & .70 & 115 & 00 \\
\hline reacner & SD & .15 & .15 & .14 & .12 & 11.5 & .00 \\
\hline & $\mathrm{M}$ & .60 & .62 & .70 & .72 & & 00 \\
\hline $\mathrm{Cl}$ & $\mathrm{SD}$ & .14 & .14 & .14 & .13 & 27.3 & .00 \\
\hline DURATIO & DN AND WI & ER & & & & & \\
\hline & $\mathrm{M}$ & .53 & .60 & .69 & .72 & & \\
\hline Child & SD & .13 & .14 & .14 & .18 & 39.2 & .00 \\
\hline Mother & M & .55 & .61 & .70 & .70 & 31.2 & .00 \\
\hline
\end{tabular}




\begin{tabular}{|c|c|c|c|c|c|c|c|}
\hline \multirow{3}{*}{ Teacher } & $\mathrm{SD}$ & .13 & .15 & .16 & .17 & \multirow{3}{*}{28.2} & \multirow{3}{*}{.00} \\
\hline & $\mathrm{M}$ & .53 & .59 & .67 & .69 & & \\
\hline & SD & .14 & .16 & .17 & .16 & & \\
\hline \multirow{2}{*}{ CI } & M & .54 & .60 & .69 & .70 & \multirow{2}{*}{25.2} & \multirow{2}{*}{.00} \\
\hline & SD & .13 & .15 & .16 & .17 & & \\
\hline \multicolumn{8}{|c|}{ CONNECTION BETWEEN CONTRIBUTION AND SHARE } \\
\hline \multirow{2}{*}{ Child } & $\mathrm{M}$ & .54 & .61 & .69 & .73 & \multirow{2}{*}{22.2} & \multirow{2}{*}{.00} \\
\hline & SD & .18 & .15 & .12 & .12 & & \\
\hline \multirow{2}{*}{ Mother } & M & .53 & .60 & .68 & .72 & \multirow{2}{*}{10.2} & \multirow{2}{*}{.02} \\
\hline & SD & .19 & 14 & .12 & .11 & & \\
\hline \multirow{2}{*}{ Teacher } & M & .54 & .59 & .68 & .70 & \multirow{2}{*}{5.4} & \multirow{2}{*}{.00} \\
\hline & SD & .22 & .16 & .14 & .11 & & \\
\hline \multirow{2}{*}{ CI } & $\mathrm{M}$ & .54 & .60 & .68 & .72 & \multirow{2}{*}{15.3} & \multirow{2}{*}{.00} \\
\hline & SD & .20 & .15 & .13 & .11 & & \\
\hline
\end{tabular}

Based on the CI, the results of the Interest (I) factor (Table 3) show that in the case of the 15- and 18-year-old students acting out of self-interest is more common than pursuing others' interest and that of common interest in group work. The older students tend to realise self-interest in competitive situations (the goal is beating the rival), too. Personal success as a main goal is more frequent among the 15- and 18-year-olds than in the two younger groups. In the case of cooperation, self-interest realisation is the most frequent goal among the 15- and 18-year-olds and it is still important among younger students. The results of the Situation and expectations (SE) factor show that, older students more frequently take into account factors other than the situation itself when making a decision (it is very important who they have to compete with) in competitive situations. In addition, parents', teachers' and peers' expectations are less important for high school students when they have to act in a competitive situation.

The results of the Equal opportunity, conflict of interests, exclusion (ECE) factor show that older students assess the chance of others for interest realisation more often than the younger children. Also, in the two older age-groups, exclusion is more frequent because of both inadequate achievement and exaggerated claims for reward. In most cases low achievement and high claims for reward together make up the cause for exclusion. According to the results of the Duration and winner (DW) factor, older children choose a competitive situation when the number of winners is one and they do not want to know too early who won (they are patient when it comes to waiting for the results). Data related to the Connection between contribution and share (CS) factor suggest that share is more often independent of contribution in the case of 8-year-olds than in the case of 12-year-olds and older children. 
Age-related changes in the CI of the five factors are shown in Figure 1. The distribution of the points of assessment is not at an equal distance; as a result, curves only approximately represent the hypothesised changes. In the case of four factors (I, ECE, CCS, DW), the curve representing the change of the assessed components corresponds to one phase of a logistic curve (the initial phase of growth is slow, then it is fast, and finally growth slows again). In the case of one factors (SE) the hypothesised age-related change goes in the opposite direction.

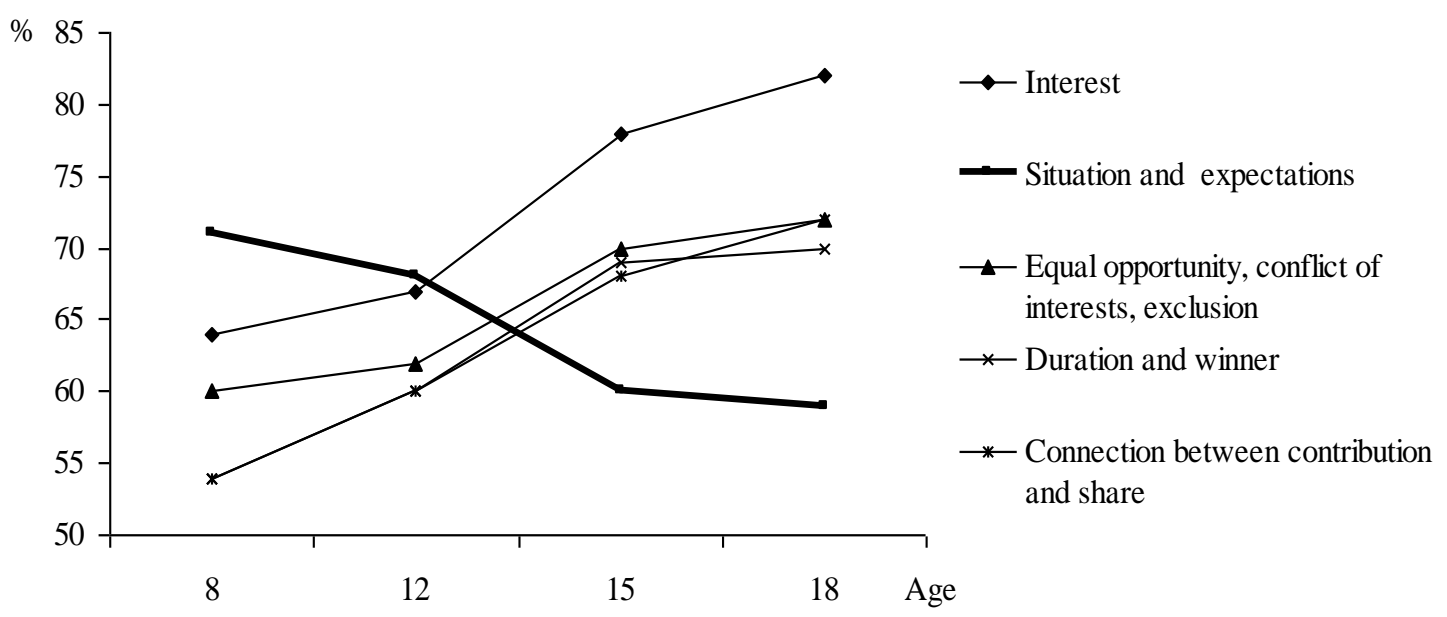

Figure 1. The functioning of factors between the ages of 8 and 18 (based on the cumulated indices)

\section{The correlation between raters' judgements}

The Pearson correlations between raters' judgements are shown in Table 4. The strongest correlation between children's and mothers' ratings was found for the Interest and Connection between contribution and share factors in all age groups (correlation values are between .39-.41). The smallest correlation values can be found in the 18-year-old sample for the Situation and expectation factor $(r=.29)$. The strongest correlation between children's and teachers' ratings was found for the Interest, Duration and winner and Connection between contribution and share factors. However, the smallest values can be found in the 15-year-olds for the Duration and winner factor $(r=.26)$. Finally, the highest correlation values between mothers' and teachers' ratings can be found for the Duration and winner and Connection between contribution and share factor $(\mathrm{r}=.32)$. In the case of 
the 15-year-old children the smallest value is at the Duration and winner factor $(\mathrm{r}=.18)$ and among the 12-year-olds this is at the Interest factor $(\mathrm{r}=.19)$.

Table 4: Pearson correlations among the raters' judgements

\begin{tabular}{|c|c|c|c|c|c|c|c|c|c|c|c|c|c|c|c|c|c|c|c|c|}
\hline \multirow[t]{3}{*}{ Raters } & \multicolumn{5}{|l|}{8} & \multicolumn{5}{|l|}{12} & \multicolumn{5}{|l|}{15} & \multicolumn{5}{|c|}{18} \\
\hline & $\mathrm{Ch}$ & & & & & $\mathrm{Ch}$ & & & & & $\mathrm{Ch}$ & & & & & $\mathrm{Ch}$ & & & & \\
\hline & I & $\begin{array}{l}\mathrm{S} \\
\mathrm{E}\end{array}$ & $\begin{array}{l}\mathrm{E} \\
\mathrm{C} \\
\mathrm{E}\end{array}$ & $\begin{array}{l}\mathrm{D} \\
\mathrm{W}\end{array}$ & $\begin{array}{l}\mathrm{C} \\
\mathrm{S}\end{array}$ & I & $\begin{array}{l}S \\
E\end{array}$ & $\begin{array}{l}\mathrm{E} \\
\mathrm{C} \\
\mathrm{E}\end{array}$ & $\begin{array}{l}\mathrm{D} \\
\mathrm{W}\end{array}$ & $\begin{array}{l}\mathrm{C} \\
\mathrm{S}\end{array}$ & I & $\begin{array}{l}S \\
E\end{array}$ & $\begin{array}{l}\mathrm{E} \\
\mathrm{C} \\
\mathrm{E}\end{array}$ & $\begin{array}{l}\text { D } \\
\text { W }\end{array}$ & $\begin{array}{l}\mathrm{C} \\
\mathrm{S}\end{array}$ & I & $\begin{array}{l}S \\
E\end{array}$ & $\begin{array}{l}\mathrm{E} \\
\mathrm{C} \\
\mathrm{E} \\
\end{array}$ & $\begin{array}{l}\mathrm{D} \\
\mathrm{W}\end{array}$ & $\begin{array}{l}\mathrm{C} \\
\mathrm{S}\end{array}$ \\
\hline $\begin{array}{l}\text { Child } \\
- \\
\text { mothe } \\
\text { r }\end{array}$ & $\begin{array}{l}.3 \\
2\end{array}$ & $\begin{array}{l}.3 \\
8\end{array}$ & $\begin{array}{l}.3 \\
5\end{array}$ & $\begin{array}{l}.3 \\
6\end{array}$ & $\begin{array}{l}.3 \\
7\end{array}$ & $\begin{array}{l}.4 \\
2\end{array}$ & $\begin{array}{l}.3 \\
6\end{array}$ & $\begin{array}{l}.3 \\
3\end{array}$ & $\begin{array}{l}.3 \\
5\end{array}$ & $\begin{array}{l}.4 \\
0\end{array}$ & $\begin{array}{l}.3 \\
9\end{array}$ & $\begin{array}{l}.3 \\
8\end{array}$ & $\begin{array}{l}.3 \\
4\end{array}$ & $\begin{array}{l}.3 \\
1\end{array}$ & $\begin{array}{l}.4 \\
1\end{array}$ & .3 & $\begin{array}{l}.2 \\
9\end{array}$ & $\begin{array}{l}.3 \\
4\end{array}$ & $\begin{array}{l}.3 \\
6\end{array}$ & $\begin{array}{l}.3 \\
6\end{array}$ \\
\hline $\begin{array}{l}\text { (2) } \\
\text { Child } \\
- \\
\text { teache } \\
\text { r } \\
\end{array}$ & $\begin{array}{l}.4 \\
0\end{array}$ & $\begin{array}{l}.3 \\
6\end{array}$ & $\begin{array}{l}.3 \\
6\end{array}$ & $\begin{array}{l}.4 \\
0\end{array}$ & $\begin{array}{l}.3 \\
5\end{array}$ & $\begin{array}{l}.3 \\
5\end{array}$ & $\begin{array}{l}.2 \\
9\end{array}$ & $\begin{array}{l}.3 \\
5\end{array}$ & $\begin{array}{l}.3 \\
9\end{array}$ & $\begin{array}{l}.3 \\
6\end{array}$ & $\begin{array}{l}.3 \\
4\end{array}$ & $\begin{array}{l}.3 \\
5\end{array}$ & $\begin{array}{l}.3 \\
5\end{array}$ & $\begin{array}{l}.2 \\
6\end{array}$ & $\begin{array}{l}.4 \\
0\end{array}$ & $\begin{array}{l}.3 \\
8\end{array}$ & $\begin{array}{l}.3 \\
2\end{array}$ & $\begin{array}{l}.2 \\
9\end{array}$ & $\begin{array}{l}.3 \\
0\end{array}$ & $\begin{array}{l}.3 \\
4\end{array}$ \\
\hline $\begin{array}{l}\text { (3) } \\
\text { Mothe } \\
r \quad- \\
\text { teache } \\
\text { r }\end{array}$ & $\begin{array}{l}.2 \\
9\end{array}$ & $\begin{array}{l}.2 \\
7\end{array}$ & $\begin{array}{l}.2 \\
8\end{array}$ & $\begin{array}{l}.2 \\
2\end{array}$ & $\begin{array}{l}.3 \\
0\end{array}$ & $\begin{array}{l}.1 \\
9\end{array}$ & $\begin{array}{l}.2 \\
2\end{array}$ & $\begin{array}{l}.3 \\
0\end{array}$ & $\begin{array}{l}.3 \\
2\end{array}$ & $\begin{array}{l}.3 \\
2\end{array}$ & $\begin{array}{l}.2 \\
2\end{array}$ & $\begin{array}{l}.2 \\
1\end{array}$ & $\begin{array}{l}.2 \\
4\end{array}$ & $\begin{array}{l}.1 \\
8\end{array}$ & $\begin{array}{l}.2 \\
7\end{array}$ & 2 & $\begin{array}{l}.2 \\
4\end{array}$ & $\begin{array}{l}.2 \\
5\end{array}$ & $\begin{array}{l}.2 \\
0\end{array}$ & $\begin{array}{l}.3 \\
1\end{array}$ \\
\hline
\end{tabular}

Note. I=Interest; SE=Situation and expectations; ECE=Equal opportunity, conflict of interests, exclusion; DW=Duration and winner; $\mathrm{CS}=$ Connection between contribution and share. $\mathrm{KMO}=$ Kaiser-Meyer-Olkin index.

Based on the z-test used to compare correlation differences, the correlations between the raters are different at the factors. In line with our hypothesis, the correlations between children's and mothers' ratings are the strongest, and the most divergent evaluations of factors were given by teachers and mothers. The results of the z-test are in the following order: age factor, (raters), $\mathrm{z}$ and $\mathrm{p}$ values. Only significant differences are presented here in detail: $8_{\mathrm{I}}(1-2) \mathrm{z}=2.04 \mathrm{p}=.041 ; 8_{\mathrm{I}}(2-3) \mathrm{z}=2.69 \mathrm{p}=.042 ; 8_{\mathrm{DW}}(2-3) \mathrm{z}=2.47$ $\mathrm{p}=.011 ; 12_{\mathrm{I}}(1-3) \mathrm{z}=2.44 \mathrm{p}=.012 ; 12_{\mathrm{I}}(2-3) \mathrm{z}=2.13 \mathrm{p}=.032 ; 12_{\mathrm{CS}}(1-3) \mathrm{z}=2.11 \mathrm{p}=.039 ; 15_{\mathrm{I}}$ (1-3) $\mathrm{z}=2.55 \mathrm{p}=.048 ; 15_{\mathrm{SE}}(1-2) \mathrm{z}=1.92 \mathrm{p}=.05 ; 15_{\mathrm{AS}}(1-3) \mathrm{z}=2.4 \mathrm{p}=.01 ; 18_{\mathrm{I}}(2-3) \mathrm{z}=1.54$ $\mathrm{p}=.045 ; 18_{\mathrm{DW}}(1-3) \mathrm{z}=.69 \mathrm{p}=.041$.

\section{School type differences among the 15- and 18-year-old students}


The hypothesis concerning the differences related to school types could be confirmed. The judges' ratings of students' behaviour change as a function of school type. Differences were found between raters, too. Most of the divergences can be identified between children's self-assessment and teachers' ratings. This holds true for all factors. Only cumulated indices (mean of the raters' judgements) are presented here in detail. Among the 15-year-olds, significant school type differences were found for all factors. Results suggest that grammar school students differ significantly from secondary vocational and vocational school students in that grammar school students scored significantly lower on the Interest factor $(\mathrm{g}: \mathrm{M}=.89, \mathrm{SD}=.10 ; \mathrm{s}: \mathrm{M}=77, \mathrm{SD}=.12 ; \mathrm{v}: \mathrm{M}$ $=72, \mathrm{SD}=.14 ; \mathrm{F}=35.2, \mathrm{p}=.01)$ and on the Duration and winner factor $(\mathrm{g}: \mathrm{M}=.74, \mathrm{SD}$ $=.15 ; \mathrm{s}: \mathrm{M}=.68, \mathrm{SD}=.13 ; \mathrm{v}: \mathrm{M}=.67, \mathrm{SD}=.19 ; \mathrm{F}=44.4, \mathrm{p}=.00)$. Also, vocational school students differ significantly from grammar school and secondary vocational school students since they have lower scores on the Situation and expectations factor $(\mathrm{g}$ : $\mathrm{M}=.65, \mathrm{SD}=.12 ; \mathrm{s}: \mathrm{M}=.63, \mathrm{SD}=.11 ; \mathrm{v}: \mathrm{M}=.55, \mathrm{SD}=.16 ; \mathrm{F}=76.1, \mathrm{p}=.00)$ and on the Connection between contribution and share factor $(\mathrm{g}: \mathrm{M}=73, \mathrm{SD}=.13 ; \mathrm{s}: \mathrm{M}=71$, $\mathrm{SD}=.12 ; \mathrm{v}: \mathrm{M}=58, \mathrm{SD}=.14 ; \mathrm{F}=29.6, \mathrm{p}=.01)$. Vocational school students also scored significantly higher than grammar school students and secondary vocational school students on the Equal opportunity, conflict of interests, exclusion factor ( $g$ : $M=.64, \mathrm{SD}$ $=.11 ; \mathrm{s}: \mathrm{M}=.66, \mathrm{SD}=.13 ; \mathrm{v}: \mathrm{M}=.79, \mathrm{SD}=.17 ; \mathrm{F}=55.9, \mathrm{p}=.00)$.

School type differences were found in the 18-year-olds for all factors and the differences are similar to those found in the 15-year-old group. Grammar school students are significantly different from secondary vocational and vocational school students in that they scored lower on the Interest factor $(\mathrm{g}: \mathrm{M}=.92, \mathrm{SD}=.11 ; \mathrm{s}: \mathrm{M}=80, \mathrm{SD}=.11$; $\mathrm{v}: \mathrm{M}=76, \mathrm{SD}=.12 ; \mathrm{F}=29.2, \mathrm{p}=.00)$, on the Duration and winner factor $(\mathrm{g}: \mathrm{M}=.76$, $\mathrm{SD}=.14 ; \mathrm{s}: \mathrm{M}=.68, \mathrm{SD}=.15 ; \mathrm{v}: \mathrm{M}=.67, \mathrm{SD}=.20 ; \mathrm{F}=53.4, \mathrm{p}=.00)$, and on the Connection between contribution and share factor $(\mathrm{g}: \mathrm{M}=.81, \mathrm{SD}=.10 ; \mathrm{s}: \mathrm{M}=.68, \mathrm{SD}$ $=.10 ; \mathrm{v}: \mathrm{M}=.66, \mathrm{SD}=.13 ; \mathrm{F}=32.4, \mathrm{p}=.00)$. Also, vocational school students differ significantly from grammar school and secondary vocational school students as they can be characterized by lower scores on the Situation and expectations factor ( $\mathrm{g}: \mathrm{M}=.63$, SD $=.13 ; \mathrm{s}: \mathrm{M}=.64, \mathrm{SD}=.11 ; \mathrm{v}: \mathrm{M}=.53, \mathrm{SD}=.16 ; \mathrm{F}=31.2, \mathrm{p}=.01)$ and on the Connection between contribution and share factor $(\mathrm{g}: \mathrm{M}=76, \mathrm{SD}=.12 ; \mathrm{s}: \mathrm{M}=76, \mathrm{SD}=$ $.11 ; \mathrm{v}: \mathrm{M}=63, \mathrm{SD}=.13 ; \mathrm{F}=79.6, \mathrm{p}=.00)$. On the other hand, vocational school students scored higher than grammar school and secondary vocational school students on 
the Equal opportunity, conflict of interests, exclusion factor $(\mathrm{g}: \mathrm{M}=.68, \mathrm{SD}=.12 ; \mathrm{s}: \mathrm{M}=$ $.70, \mathrm{SD}=.12 ; \mathrm{v}: \mathrm{M}=.78, \mathrm{SD}=.16 ; \mathrm{F}=65.9, \mathrm{p}=.00)$.

\section{Correlations of cooperation and competition factors}

Results of the factor analysis suggest that the studied behaviours share several factors. These results show the structure of the behaviours. Correlation analyses were done to explore the relationship of the factors (Figure 2).

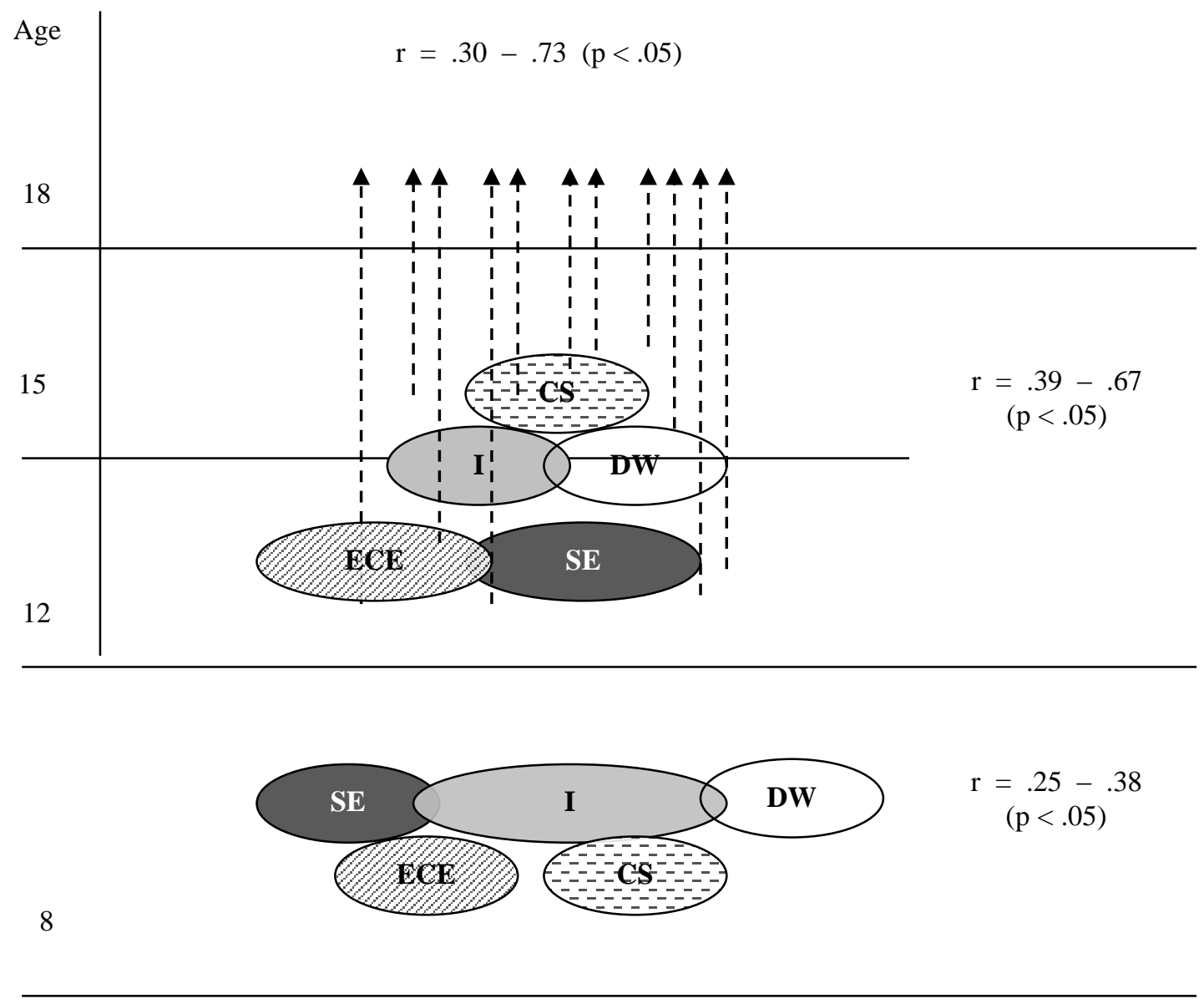

Figure 2. The system of factors and the change of connections with age

The Interest (I) factor is related to other factors in the 8-year-olds, and we have found a connection between Situation and expectations (SE) and Equal opportunity, conflict of interests, exclusion (ECE) factors, as well. The correlations are low on the whole sample $(\mathrm{I} \times \mathrm{DW}=.30 ; \mathrm{I} \times \mathrm{CS}=.33 ; \mathrm{I} \times \mathrm{ECE}=.31 ; \mathrm{I} \times \mathrm{SE}=.38 ; \mathrm{SE} \times \mathrm{ECE}=.27)$. The correlation of I x SE decreases with age (18: $\mathrm{r}=.25$ among the 18-year-olds); but the correlation values between I x DW, I x CS and I x ECE show an increasing tendency with 
age (18: I x DW r $=.52 ; 18$ : 18: I x CS r $=.68 ; 18$ : I x ECE $r=.73)$. DW x SE (12-18: $r$ $=.55-.63)$ and DW x CS $(12-18: \mathrm{r}=.67-.71)$ are also important links in the factor system at the ages of $12-18$.

\section{Characteristics of family background}

Mothers specified the family type (FT) in the first part of the questionnaire. Based on their answers, a system of categories was developed (see Instruments). The distributions of the FT categories are similar in the four child age groups. The first category (mother and father with child) has the largest percentage (44-56\%). The aggregate distribution of the first, second (18-25\%, mother and father with two or more children) and third (12$20 \%$, mother with one child) categories are about $80 \%$ in all age groups. The distribution of categories is not different between the age groups $\left(\chi^{2}=5.28, \mathrm{p}=.62\right)$.

The sample and the subsamples represented a range of Hungarian mothers' educational levels (1: elementary school $=19-26 \% ; 2$ : vocational school $=31-35 \% ; 3$ : high school $=33-38 \%$; 4 : college or university degree $=5-9 \%$; whole sample: $\chi^{2}=53.12, p=.02$ ). The distribution of fathers' educational levels is the same in the whole sample and in the subsamples, as well: $1=21-35 \% ; 2=33-46 \% ; 3=26-34 \% ; 4=4-10 \%$. For the whole sample: $\chi^{2}=28.45, \mathrm{p}=.04$.

The net income (NI) section includes answers about the financial circumstances defined as net income per capita per month (based on the valid Hungarian income system in 2010; the system was presented for the parents in the appendix of the questionnaire). The distributions of NI categories are also similar in all age groups. The third category (average) has the largest percentage (39-52\%), and the aggregate distribution of the third and first (14-21\%, very bad) and second (11-16\%, wrong) categories are about $70 \%$ in all age groups. The distribution of categories is not different between the child age groups $\left(\chi^{2}=12.34, p=.71\right)$.

Free time activities with child in family (FTA) designates the time spent on a free time activity (e.g. play, watching TV, cinema or theatre, conversation) with children in a week. The distributions of FTA categories are different in the whole sample $\left(\chi^{2}=35.41\right.$, $\mathrm{p}=.03$ ). In the 8- and 12-year-old groups the distributions are similar: the aggregate distribution of first, second and third categories are $79 \%$ and $74 \%$. In the case of the 15 and 18-year-olds the first, second and third categories are $66 \%$ and $60 \%$. Most of the 15- 
and 18 -year-old children $(81 \%)$ live at home, not in a dormitory, which may explain the difference in the distribution of categories.

The TSL (time spent on learning with child) categories are the same as the FTA categories. The proportion of FTA categories changes with time $\left(\chi^{2}=24.25, \mathrm{p}=.02\right)$. Among the 8- and 12-year-olds the proportion of categories 1-2 and 4-5 are the same (8: $25 \%, 28 \% ; 12: 25 \%, 29 \%$ ), and the distributions are significantly different from those of the categories of the two older age groups $\left(15_{1-2}\right.$ and 4-5: $42 \%$ and $19 \% ; 18_{1-2}$ and $4-5: 59 \%$ and $17 \%)$.

\section{Relationship between cooperation and competition factors and family background}

The relationship between cooperation and competition factors and the characteristics of family background was examined with regression analyses. In all age-groups the dependent variables were the five social factors (I, SE, ECE, DW, CS) and the independent variables were the five social factors and FT, MEL, FEL, NI, FTA, TSL (family background). The results are presented in Tables 6 to 9 .

Table 6: The impact of independent variables on factors (rounded \%, 8-year-olds)

\begin{tabular}{|c|c|c|c|c|c|}
\hline \multirow{2}{*}{ Independent variables } & \multicolumn{5}{|c|}{ "Cooperation and competition factors } \\
\hline & $\mathrm{I}$ & $\mathrm{SE}$ & ECE & DW & $\mathrm{CS}$ \\
\hline Interest (I) & & 10 & 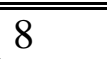 & 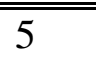 & 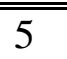 \\
\hline Situation and expectations (SE) & 8 & & 7 & 1 & 1 \\
\hline $\begin{array}{l}\text { Equal opportunity, conflict of interests, } \\
\text { exclusion (ECE) }\end{array}$ & 8 & 7 & & 4 & 8 \\
\hline Duration and winner (DW) & 3 & 2 & 3 & & 4 \\
\hline $\begin{array}{l}\text { Connection between contribution and share } \\
\text { (CS) }\end{array}$ & 2 & 3 & 4 & 4 & \\
\hline Family type (FT) & 11 & 9 & 7 & 6 & 12 \\
\hline Mother's educational level (MEL) & 8 & 4 & 5 & 2 & 3 \\
\hline Father's educational level (FEL) & 3 & 2 & 3 & 7 & 2 \\
\hline Net income (NI) & 2 & n. s. & n. s. & n. s. & 2 \\
\hline Free time activities in family (FTA) & 3 & 3 & 2 & 3 & 4 \\
\hline $\begin{array}{l}\text { Time spent on learning with children } \\
\text { (TSL) }\end{array}$ & 2 & 5 & n. s. & n. s. & 2 \\
\hline Explained variance $\left(\mathrm{r}^{*} \beta, \%\right)$ & 50 & 45 & 39 & 32 & 43 \\
\hline
\end{tabular}

Note. $\mathrm{p}<.05$; n. s. not significant

Table 7: The impact of independent variables on factors (rounded \%, 12-year-olds) 


\begin{tabular}{|c|c|c|c|c|c|}
\hline \multirow{2}{*}{ Independent variables } & \multicolumn{5}{|c|}{ Cooperation and competition factors } \\
\hline & $\mathrm{I}$ & $\mathrm{SE}$ & ECE & DW & $\mathrm{CS}$ \\
\hline Interest (I) & & 12 & 8 & 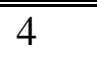 & 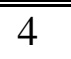 \\
\hline Situation and expectations (SE) & 9 & & 6 & 1 & 3 \\
\hline $\begin{array}{l}\text { Equal opportunity, conflict of interests, } \\
\text { exclusion (ECE) }\end{array}$ & 7 & 6 & & 3 & 5 \\
\hline Duration and winner (DW) & 2 & 3 & 4 & & 3 \\
\hline $\begin{array}{l}\text { Connection between contribution and share } \\
\text { (CS) }\end{array}$ & 4 & 2 & 4 & 5 & \\
\hline Family type (FT) & 10 & 7 & 5 & 4 & 9 \\
\hline Mother's educational level (MEL) & 7 & 5 & 5 & 3 & 5 \\
\hline Father's educational level (FEL) & 4 & 2 & n. s. & 7 & 1 \\
\hline Net income (NI) & 2 & 1 & n. s. & n. s. & 3 \\
\hline Free time activities in family (FTA) & 5 & 4 & 3 & 3 & 5 \\
\hline $\begin{array}{l}\text { Time spent on learning with children } \\
\text { (TSL) }\end{array}$ & 2 & 2 & 2 & n. s. & 3 \\
\hline Explained variance $\left(\mathrm{r}^{*} \beta, \%\right)$ & 52 & 44 & 37 & 30 & 41 \\
\hline
\end{tabular}

Note. $\mathrm{p}<.05 ;$ n. $\mathrm{s}$. not significant

Table 8: The impact of independent variables on factors (rounded \%, 15-year-olds)

\begin{tabular}{|c|c|c|c|c|c|}
\hline \multirow{2}{*}{ Independent variables } & \multicolumn{5}{|c|}{ Cooperation and competition factors } \\
\hline & I & SE & ECE & DW & $\mathrm{CS}$ \\
\hline Interest (I) & & 13 & 10 & 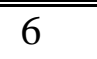 & 6 \\
\hline Situation and expectations (SE) & 11 & & 7 & n. s. & n. $\mathrm{s}$ \\
\hline $\begin{array}{l}\text { Equal opportunity, conflict of interests, } \\
\text { exclusion (ECE) }\end{array}$ & 9 & 7 & & 5 & 7 \\
\hline Duration and winner (DW) & 5 & 3 & 2 & & 4 \\
\hline $\begin{array}{l}\text { Connection between contribution and share } \\
\text { (CS) }\end{array}$ & 5 & 3 & 3 & 4 & \\
\hline Family type (FT) & 9 & 6 & 6 & 5 & 10 \\
\hline Mother's educational level (MEL) & 9 & 4 & 4 & 5 & 8 \\
\hline Father's educational level (FEL) & 3 & 3 & 4 & 9 & 3 \\
\hline Net income (NI) & 1 & 1 & n. s. & n. s. & n. $\mathrm{s}$ \\
\hline Free time activities in family (FTA) & 5 & 6 & 5 & 4 & 5 \\
\hline $\begin{array}{l}\text { Time spent on learning with children } \\
\text { (TSL) }\end{array}$ & 2 & 2 & n. s. & n. s. & 1 \\
\hline Explained variance $\left(\mathrm{r}^{*} \beta, \%\right)$ & 59 & 48 & 41 & 38 & 44 \\
\hline
\end{tabular}

Note. $\mathrm{p}<.05 ;$ n. s. not significant

Table 9: The impact of independent variables on factors (rounded \%, 18-year-olds)

\begin{tabular}{|c|c|c|c|c|c|}
\hline \multirow{2}{*}{ Independent variables } & \multicolumn{5}{|c|}{ בCooperation and competition factors } \\
\hline & $\mathrm{I}$ & $\mathrm{SE}$ & ECE & DW & $\mathrm{CS}$ \\
\hline Interest (I) & & 13 & 11 & 9 & 8 \\
\hline Situation and expectations (SE) & 12 & & 8 & 1 & 1 \\
\hline $\begin{array}{l}\text { Equal opportunity, conflict of interests, } \\
\text { exclusion (ECE) }\end{array}$ & 11 & 8 & & 4 & 8 \\
\hline
\end{tabular}




\begin{tabular}{llllll} 
Duration and winner (DW) & 5 & 2 & 3 & & 4 \\
$\begin{array}{l}\text { Connection between contribution and share } \\
\text { (CS) }\end{array}$ & 7 & 2 & 2 & 4 & \\
Family type (FT) & 8 & 7 & 5 & 5 & 9 \\
Mother's educational level (MEL) & 7 & 4 & 3 & 5 & 6 \\
Father's educational level (FEL) & 5 & 3 & 5 & 8 & 2 \\
Net income (NI) & n. s. & n. s. & 1 & n. s. & n. s. \\
$\begin{array}{l}\text { Free time activities in family (FTA) } \\
\text { Time spent on learning with children }\end{array}$ & 2 & 6 & 5 & 3 & 5 \\
(TSL) & 2 & n. s. & n. s. & 1 \\
\hline Explained variance (r* $\beta, \%)$ & 61 & 47 & 43 & 39 & 44 \\
\hline \hline
\end{tabular}

Note. $\mathrm{p}<.05 ; \mathrm{n}$. s. not significant

Based on the age groups and the cooperation and competition factors, the explained variances are nearly similar, except for Interest and Duration and winner. In the case of the two factors moderate increases were detected (I: 8: 50\% $\rightarrow$ 18: 61\%; DW: $8: 32 \% \rightarrow$ 18: $39 \%$ ). In the case of the Interest factor the effects of Situation and expectations and Equal opportunity, conflict of interests, exclusion factors are strong in all age groups. The impacts of other cooperation and competition factors are smaller and they are similar in all age groups. The Interest and the Equal opportunity, conflict of interests, exclusion factors provide nearly half of the explained variance for the Situation and expectations factor in all age groups. The Interest and Situation and expectations factors have a significant role in the explained variance of Equal opportunity, conflict of interests, exclusion. The effects of the Duration and winner and Connection between contribution and share are low and similar in all age groups. For the Duration and winner factor the effects of other cooperation and competition factors are very low and similar in all age groups. For the Connection between contribution and share factor the largest proportion of the explained variance is given primarily by two factors (Interest; Equal opportunity, conflict of interests, exclusion).

The variances of the family characteristics are also nearly similar in all age groups. The values of Interest are the highest and the values of Equal opportunity, conflict of interests, exclusion are the lowest in all age groups. FT plays a considerable role in the development of Interest and Connection between contribution and share factors in all age groups. Also, the MEL has a significant effect on these factors and the FEL has an effect on Duration and winner in all age groups. The effects of FTA are stronger than those of TSL in all age groups, however, these effects are quite weak. Net income is the environment variable that has the smallest effect on the assessed factors. 


\section{Discussion}

According to Fiske (2006) children's self-interest realisation shows an increasing tendency with age. The same change was found in the case of the Interest factor as well. Data suggest that during high school years self-interest more often determines the acceptance of the direction of competition and cooperative situation, work in group. This tendency is in connection with other changes of behaviour, for example the 15- and 18old children are characterised the least and 8-year-olds the most by accepting rewards regardless of contribution (Connection between contribution and share). In addition, the 15- and 18-year-old children are less likely to take into consideration parents', teachers' and peers' expectations while respecting competition rules (Situation, expectations). In connection with the results of the Situation and expectations factor, Froming, Nasby and McManus (1998) emphasize that the different external (for example parental or peer) expectations are interiorised in an increasing measure with age. Fiske's (2006) ideas: younger children (in our study the 8- and the 12-year-olds) are more likely to respect rules and they adapt to norms and customs better than their older mates. Caplan and Hay (1989) got similar results on this subject.

In the case of equality of competition the interest of others is often more important in the two older groups, and they more often take into consideration others' chances for winning when they compete. For example they prefer competitions where each competitor has the biggest chance possible to win. It is also more frequent among them to exclude someone from a group because of insufficient contribution of inadequate claims for reward (Equal opportunity, conflict of interests, exclusion). These results point to the necessity of a multidimensional assessment of these behaviours (Fülöp, 2010).

High school age students more often choose situations when only one person has a chance to win, more often consider peers as adversaries even when the competition has ended, and they more often think that competitions do not have time limits (Duration and winner). If we consider the results of the competition as a reward, the results are related to children's ability to endure delay. Cole and Cole (2006) suggest that this ability improves with age, and this is what was confirmed by my study, too. According to Sándor and Fülöp (2005), conceptual development is closely related to the age-related changes of children's notion of competition: before the age of 10 fundamental concepts 
(for example competition, victory, losing) are taken structurally (for example in the form of a match, a musical or a sport competition), the concept of competition based on a social comparison is evolving at this age (Fülöp, 2007).

The dimension-based investigations showed that some dimensions of cooperation and competition have a strong correlation with age (e.g. Charlesworth, 1996; Van de Vliert, 1999; Fülöp, 2010). In line with these international results, the correlations of cooperation and competition dimensions are significant. Our data suggest that the following factors significantly determine each other before high school years: conflict of interest in a group, exclusion from a group (that of oneself and of others), respecting rules of competition. The relations between these dimensions do not change during high school years.

School type had a significant effect on students' social achievement among 15and 18-year-olds, and the three raters have very different opinions on students' social behaviours studied here. Most of the differences can be identified between children's self-assessment and teachers' ratings. Parents and students differ only on some items of the Interest and Situation and expectation factors, and parents' and teachers' opinions are in a contradiction in each case. Students' and teachers' assessments nearly always show high correspondence. In most cases, it is grammar school students who can be distinguished from secondary vocational school and vocational school students. The results show that raters' judgements differ the least according to age and the most according to school types, and that teachers' opinions differ significantly from those of parents' and children's. According to Anderson (2000), this phenomenon fundamentally and usually negatively influences the effectiveness of development programs in kindergartens and schools.

The results of regression analyses clearly support international research results (e.g. Grusec \& Hastings, 2007) in suggesting that family characteristics must be paid more attention to in the future when elaborating a specific social developmental program. Based on the explained variances, family type plays a significant role in the development of all factors in all age groups. As shown in earlier Hungarian studies (e.g. Zsolnai \& Kasik, 2011), mothers' educational level has a significant effect on factors. We have found that fathers' educational level has also a significant impact on these factors. However, parents' educational levels influence the factors differently: mothers' educational level has an effect on Interest and Connection between contribution and share, and fathers' educational level has an impact on Duration and winner in all age 
groups. Mothers strongly distinguish between cooperation and competition: they think that their children's cooperative behaviour depends mostly on family education while competition should be acquired in schools and the cooperation is a positive behaviours and the competition is a negative behaviour. However, the fathers emphasize that the competitive situations are very important in childhood. Numerous surveys show that mothers' opinions about cooperation and competition are different from those of fathers (e.g. Schneider, 1993). This approach has an effect on children's attitudes to these behaviours and on the acquisition and application of knowledge related to the behaviours.

According to Grusec and Davidov (2007), family activity has a vital influence on children's thinking and behaviour. During free time activities and when learning with children, parents may indirectly teach several social patterns to their children. In the present study, the time that parents spent with children learning and during free time activities decrease with age. For all groups, the effects of free time activities in family are stronger than those of the time spent learning with children. However, these family components have a low impact on cooperation and competition factors. The net income has the smallest effect on the studied social components.

The effectiveness and the success of education depends largely on how much we know about the functioning of the psychic components which we would like to develop, and about the role that environment variables play in the development of these components. The significance of the empirical study lies in the fact that it explored the characteristics of cooperation and competition by age and school type in detail. Reliable investigations of these components have been scarce until now. The results support many previous, predominantly international research results, and stimulate rethinking our knowledge about the functioning of behaviours and about the possibilities of their development. They also provide an adequate basis for designing a complex program promoting the development of social behaviour of children between 8 and 18 . Complexity means here that the program involves direct, indirect and context-embedded tasks.

\section{References}

Anderson, P. L. (2000). Using literature to teach social skills to adolescent with LD. Intervention in School and Clinic, 35, 271-279. doi: 10.1177/105345120003500503 
Baron, J. (1997). The illusion of morality as self-interest: A reason to cooperate in social dilemmas. Psychological Science, 8, 330-335. doi: 10.1111/j.1467-9280.1997.tb00448

Bettencourt, B. A. \& Sheldon, K. (2001). Social goals as mechanism for psychological need satisfaction within social groups. Journal of Personality and Social Psychology, 81, 1131-1141. doi: 10.1037/0022-3514.81.6.1131

Bremer, C. D. \& Smith, J. (2004). Teaching Social Skills. Addressing Trends and Developments in Secondary Education and Transition, 5.

Caplan, M. Z. \& Hay, D. F. (1989). Preschoolers' responses to peer distress and beliefs about bystander intervention. Journal of Child Psychology and Psychiatry, 30, 231-241.

Caprara, G. V., Barbaranelli, C., Pastorelli, C., Bandura, A., \& Zimbardo, P. G. (2000). Prosocial foundations of children's academic achievement. Psychological Science, 11, 302-306. doi: 10.1111/1467-9280.00260

Charlesworth, W. R. (1996). Co-operation and competition: contributions to an evolutionary and developmental model. International Journal of Behavioral Development, 19(1), 25-39.

Cole, M. \& Cole, S. (2006). Fejlödéslélektan [The Development of Children]. Budapest: Osiris Kiadó.

Conger, R. D. \& Dogan, S. J. (2007). Social class and socialization in families. In J. Grusec, \& P. Hastings (eds.), Handbook of Socialization. (pp. 433-460) New York: Guildford Press.

Csányi, V. (1999). Az emberi természet [ On Human Nature) ]. Budapest: Vince Kiadó.

Csapó, B. (2000). A tantárgyakkal kapcsolatos attitüdök összefüggései [ Students' attitudes towards school subjects ]. Magyar Pedagógia, 100(3), 343-365.

Decety, J., Jackson, P. L., Sommerville, J., Chaminade, T., \& Meltzoff, A. N. (2004). The neural bases of cooperation and competition: an fMRI investigation. NeuroImage, 23, 744-751. doi:10.1016/j.neuroimage.2004.05.025

Deutsch, M. (1949). A theory of cooperation and competition. Human Relations, 2, 129152.

Deutsch, M. (2000). Cooperation and Competition. In M. Deutsch \& P. Coleman (eds.) The Handbook of Conflict Resolution: Theory and Practice. San Francisco: Jossey-Bass Publishers.

Eibl-Eibesfeldt, I. (1989). Human Etology. New York: Aldine de Gryter.

Eisenberg, N. (1982). The development of reasoning regarding prosocial behavior. In N. Eisenberg (ed.), The Development of Prosocial Behavior. New York: Academic Press.

Fiske, A. P. (1992). The Cultural Relativity of Selfish Individualism: Anthropological Evidence that Humans are Inherently Sociable. In M. S. Clark (ed.), Prosocial Behaviour. Newbury Park: SAGE Publication.

Fiske, S. T. (2006). Társas alapmotívumok (Five Core Social Motives). Budapest: Osiris Kiadó.

Froming, W. J., Nasby, W., \& McManus, J. (1998): Prosocial self schemata, self awareness, and children's prosocial behavior. Journal of Personality and Social Psychology, 75, 766-777. 
Fülöp, M. (1995). A versengésre vonatkozó tudományos nézetek [ Scientific views of competition]. Pszichológia, 15(1) 61-111.

Fülöp, M. (2003). A versengés mint szociális készség fejleszthetősége [ Possibilities of development of social skills [. In Zsolnai A. (ed.), Szociális kompetencia - társas viselkedés. (170-192) Budapest: Gondolat Kiadó.

Fülöp, M. (2007). A sokarcú versengés [ The multifaceted competition ]. In Czigler I. \& Oláh A. (eds.): Találkozás a pszichológiával (228-259) Budapest: Osiris Kiadó.

Fülöp, M. (2008). Paradigmaváltás a versengéskutatásban [ Paradigm shift in research of competition [. Pszichológia, 28(2), 113-140.

Fülöp, M. (2009). Az együttműködő és versengő állampolgár nevelése: osztálytermi megfigyelések [Socialization for Cooperative and Competitive Citizen: A Classroom Observation Study]. Iskolakultúra, 19(3-4), 41-59.

Green, K., Forehand, R., Beck, S., \& Vosk, B. (1980). An assessment of the relationship among measures of children's social competence and children's academic achievement. Child Development, 51, 1149-1156.

Grusec, J. E. (1992). Socializing Concern for Others in the Home. Developmental Psychology, 27(2) 338-342. doi: 10.1037/0012-1649.27.2.338

Grusec, J. E. and Davidov, M. (2007). Socialization in the family: The roles of parents. In J. Grusec, and P. Hastings (Eds.), Handbook of Socialization (284-308). New York: Guildford Press.

Grusec, J. E. \& Hastings, P. (2007) (eds.). Handbook of Socialization. New York: Guildford Press.

Hartup, W. W. (1992). Friendship and their Developmental Significance. In H. McGurk, H. (ed.), Children's Social development. (pp. 175-205) London: Hillsdale NJ.

Kasik, L. (2008). Cooperation and Competition Questionnaire. University of Szeged.

Kasik, L. (2010). Family Background Questionnaire. University of Szeged.

Keith, L. \& Cambell, J. (2000). Assessment of Social and Emotional Development. In L. Keith \& J. Cambell (2000) (eds.), Preschool Children. The PsychoEducational Assessment Of Preschoolers (pp. 364-382) Nerdham Heights: Allyn and Becan.

Kohn, M. L. (1995). Social structure and personality through time and space. In P. Moen, G. H. Elder, \& K. Lüscher, K. (eds.), Examining lives incontext: Perspective on the ecology of human development. (pp. 141-168) Washington: American Psychological Association Press.

Ladd, G. W. (2000). The fourth R: Relationships as risks and resources following children's transition to school. American Educational Research Association Division Newsletter, 19(1) 7-11.

Lata, Chhikara, S. (1995). Adaptive behaviour of children and related factors. Hitotsubhashi Journal of Social Studies, 27, 27-28.

McClintock, C. G. (1976). Social motivations in settings of outcome interdependence. In D. Druckman (ed.), Negotiations: Social-psychological Perspectives. Sage, Beverly Hills.

Md. Aris Safree \& Mariam Adawiah (2011). The Relationship between Social Support and Academic Achievement. International Journal of Humanities and Social Science 1(5) $277-281$. 
Nagy, J. (2000). XXI. század és nevelés [ Education and the 21th century]. Budapest: Osiris Kiadó.

Orosz, G. (2009). Social Representation of competition, fraud, and academic cheating of French and Hungarian Citizens. ELTE Pszichológiai Doktori Iskola és Ecole Doctorale SHS, Université de Reims, Reims, Champagne-Ardenne.

Pruitt, D. G. (1998). Social conflict. In T. D. Gilbert, S. T. Fiske, \& G. Lindzey (eds.), Handbook of social psychology (pp. 470-503) New York: McGraw-Hill.

Sándor, M. \& Fülöp, M. (2005). Concepts on competition in 8-9 years old children (presentation, CD-ROM). XII ${ }^{\text {th }}$ European Conference on Developmental Psychology. August 24-28, Tenerife, Spain.

Schaffer, H. R. (1996). Social Development. Oxford: Blackwell.

Schneider, B. H. (1993). Childrens social competence in context. Oxford: Pergamon Press.

Schroeder, D. A., Penner, L., Dovidio, J. F., \& Piliavin, J. A. (1995). The psychology of helping and altruism: Problems and puzzles. New York: McGraw-Hill.

Strayer, F. F. (1989). Co-adaptation within the Early Peer Group: A Psychobiological Study of Social Competence. In B. H. Schneider, G. Attili, \& N. R. P. Weissberg (eds.), Social Competence in Developmental Perspective (pp. 145-175) London: SAGE.

Trivers, R. L. (1985). Social evolution. Menlo Park: Benjamin/Cummings.

Van de Vliert, E. (1999). Cooperation and Competition as Partners. European Review of

Social Psychology, 10, 231-257 doi:10.1080/14792779943000071

Van der Zee, K. I., Thijs, M. \& Schakel, L. (2002). The relationship of emotional intelligence with academic intelligence and the Big Five. European Journal of Personality, 16, 103-125. doi: 10.1002/per.434

Zsolnai, A. \& Kasik, L. (2011). Development of coping strategies and social problem solving at the ages of 8 and 12. In: Bente Wold (Ed.): Proceeding of the XV. European Conference on Developmental Psychology. Bergen, Norway, August, 23-27. Medimond, Bologna. 